\title{
Pengaruh Model Pembelajaran Group Investigation Berbantuan Media Flash Card terhadap Kompetensi Pegetahuan IPA
}

\author{
Maria Petronela Eka Lengari ${ }^{*}$, Gusti Ngurah Sastra Agustika² \\ ${ }^{12}$ Jurusan Pendidikan Dasar, Universitas Pendidikan Ganesha, Singaraja, Indonesia
}

\begin{abstract}
Abstrak
Penelitian ini bertujuan untuk mengetahui perbedaan yang signifikan kompetensi pengetahuan IPA antara kelompok siswa yang dibelajarkan melalui model pembelajaran Group Investigation berbantuan media flash card dengan kelompok siswa yang dibelajarkan melalui pembelajaran konvensional pada kelas $\mathrm{V}$

Kata Kunci:

Group Investigation, Flash Card, Kompetensi Pengetahuan IPA SD Negeri Gugus I Kuta Utara Tahun Ajaran 2018/2019. Rancangan penelitian Eksperimen semu dengan bentuk non-equivalent control group design. Populasi penelitian ini adalah kelas V SD Negeri Gugus I Kuta Utara yang terdiri dari 523 orang. Sampel penelitiannya adalah Kelas VB SD No. 4 Dalung sebagai kelompok eksperimen sebanyak 30 orang siswa dan Kelas VA SD No. 5 Dalung sebagai kelompok kontrol sebanyak 33 orang siswa yang diperoleh melalui teknik random sampling. Metode yang digunakan dalam penelitian ini adalah metode tes dengan tes pilihan ganda biasa. Hasil penelitian yang diperoleh menunjukkan bahwa rata-rata kompetensi pengetahuan IPA pada kelompok eksperimen yaitu, 79,90 dan rata-rata kompetensi pengetahuan IPA pada kelompok kontrol yaitu, 69,85. Data dianalisis dengan menggunakan uji-t, diperoleh thitung yaitu 5,003

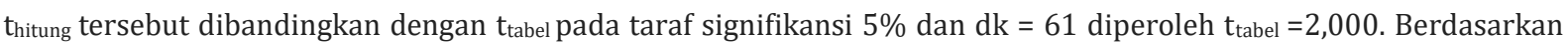
kriteria pengujian, diperoleh $t_{\text {hitung }}>t_{\text {tabel, }}$ maka $\mathrm{H}_{\mathrm{o}}$ ditolak dan $\mathrm{H}_{\mathrm{a}}$ diterima. Berarti terdapat perbedaan signifikan kompetensi pengetahuan IPA antara kelompok siswa yang dibelajarkan melalui model pembelajaran Group Investigation berbantuan media flash card dengan kelompok siswa yang dibelajarkan melalui pembelajaran konvensional pada siswa kelas V SD Negeri Gugus I Kuta Utara Tahun Ajaran 2018/2019. Dapat disimpulkan, model pembelajaran Group Investigation berbantuan media flash card berpengaruh terhadap kompetensi pengatahuan IPA siswa kelas V SD Negeri Gugus I Kuta Utara.
\end{abstract}

\section{Abstract}

This research is conducted to recognize the significant differences of the Science knowledge competencies between two groups of students of $5^{\text {th }}$ graders in two of SD Negeri Gugus I Kuta Utara, Academic Year 2018/2019. The first group was given the learning using Group Investigation learning model assisted by flash card. While the second group was given the learning using a conventional learning approach. This is a quasi-experimental research which was designed by nonequivalent group control. The population of this research is 523 fifth graders of the two SD Negeri Gugus I Kuta Utara. The first sample was 30 students from Class B of

\section{Keywords:}

Group Investigation, Flash Card, Science Knowledge

Competence 
SD No. 4 Dalung, as an experimental class and the other 33 students from Class A of SD No. 5 Dalung as a control class. These were obtained through a random sampling technique. The method used in this research was a test method which specifically applied an objective test with multiple choice. The data were analyzed by using t-test. The result obtained showed that the average competence of science in the experimental group is 79,90 and the average knowledge competence of science in the control group is 69,85 . Based on the result of significance $5 \%$ and $\mathrm{df}=61$, it is obtained $t_{\text {count }}=5,003$ and $t_{\text {table }}=2,000$ therefore $\left(t_{\text {count }}>t_{\text {table }}\right.$ ) and $H_{0}$ are disapproved while $\mathrm{H}_{\mathrm{a}}$ is received. Based on the result, it can be concluded that there are significant differences between the group of students given learning through the Group Investigation learning model assisted by flash card and the group of students who were given the learning through a conventional learning approach. Therefore, it is claimed that a Group Investigation assisted flash card approach gives a positive impact on science competencies of the fifth graders of SD Negeri Gugus I Kuta Utara.

\section{PENDAHULUAN}

Pendidikan adalah usaha sadar dan terencana untuk mewujudkan suasana belajar dan proses pembelajaran agar peserta didik secara aktif mengembangkan potensi dirinya untuk memiliki kekuatan spiritual keagamaan, pengendalian diri, kepribadian, kecerdasan, akhlak mulia, serta keterampilan yang diperlukan dirinya, masyarakat, bangsa dan negara (UU No.20 tahun 2003). Menurut Sahroni (2017). Pendidikan merupakan suatu system yang teratur dan mengemban misi yang cukup luas yaitu segala sesuatu yang bertalian dengan perkembangan fisik, kesehatan, keterampilan, pikiran, perasaan, kemauan, sosial, sampai kepada masalah kepercayaan atau keimanan. Menurut Omeri (2015) Pendidikan merupakan bagian penting dari kehidupan manusia yang tak pernah ditinggalkan.Sebagai sebuah proses, ada dua hal asumsi yang berbeda mengenai pendidikan dalam kehidupan manusia. Pendidikan juga merupakan kunci kemajuan suatu bangsa. Seperti yang diketahui, dunia kini berubah sangat cepat akibat temuan-temuan yang ditemukan dalam berbagai bidang yang disebabkan oleh adanya pendidikan. Dengan pengetahuan yang dimiliki, manusia dapat melakukan inovasi untuk meningkatkan kesejahteraan masyarakat dan membangun peradaban. Apalagi di masa yang akan datang kemajuan suatu bangsa sangat ditentukan oleh kemampuan sumber daya manusia yang dimiliki suatu bangsa dalam menguasai ilmu pengetahuan dan teknologi. Salah satu cara untuk mewujudkannya adalah dengan memiliki sumber daya manusia yang selalu haus akan ilmu dan senantiasa belajar sepanjang hayat.

Khodijah (2014:49) mengatakan, "belajar adalah proses perolehan berbagai kompetensi, keterampilan, dan sikap". Para ahli mengemukakan pendapatnya mengenai teori belajar. Salah satunya adalah Lev S. Vygotsky yang mengemukakan pendapatnya dalam teori belajar konstruktivisme. Teori konstruktivisme memiliki satu prinsip yang mendasar yaitu guru tidak hanya memberikan pengetahuan kepada siswa, namun siswa juga harus berperan aktif membangun sendiri pengetahuannya di dalam memorinya. Belajar menurut teori konstruktivisme bukanlah sekedar menghafal, akan tetapi proses mengkonstruktivisme pengetahuan pengalaman.

Parwati, dkk (2018:86) menjelaskan, tiga penekanan dalam teori belajar konstruktivisme, yaitu 1) peran aktif peserta didik dalam mengonstruksi pengetahuan secara bermakna; 2) pentingnya membuat kaitan antara gagasan dalam pengonstruktian secara bermakna; dan 3) mengaitkan antara gagasan dengan informasi yang baru diterima.

IPA adalah salah satu kompetensi pengetahuan yang dianggap paling sesuai dengan karakteristik teori konstruktivisme. IPA menurut Nash (Samatowa, 2010: 3) adalah satu cara atau metode untuk mengamati alam. Cara IPA mengamati dunia bersifat analisis, lengkap, cermat, serta menghubungkannya antara suatu fenomena dengan fenomena lain, sehingga keseluruhannya membentuk suatu perspektif yang baru tentang objek yang diamatinya. IPA perlu diajarkan pada generasi-generasi penerus bangsa. Khususnya bagi anak-anak di SD karena mereka sudah mulai menggunakan logika yang memadai. Anak juga siap untuk belajar IPA karena anak-anak dapat memenuhi tiga unsur yang ada pada sains yang dibagi oleh Carin dan Sund yaitu unsur proses, produk dan sikap. 
Samatowa (2010:104) mengatakan tujuan utama pembelajaran IPA di SD adalah membantu siswa memperoleh ide, pemahaman, dan keterampilan (life skill) esensial sebagai warga Negara. Life skills esensi yang perlu dimiliki siswa adalah kemampuan menggunakan alat tertentu, kemampuan mengamati benda dan lingkungan sekitarnya, kemampuan mendengarkan, kemampuan berkomunikasi secara efektif, menanggapi dan memecahkan masalah secara efektif. Agar tujuan utama pembelajaran ini dapat tercapai hendaknya guru dapat merancang kegiatan proses belajar mengajar yang sesuai.

Berdasarkan hasil wawancara dan observasi pada tanggal 8 dan 9 November 2018 diketahui bahwa kini khususnya di SD Negeri Gugus I Kuta Utara sudah mulai menerapkan kurikulum 2013 disetiap tingkatan kelas. Dalam proses pembelajaran dengan kurikulum 2013, diharapkan siswa menjadi lebih aktif dan mampu merefleksikan materi ajar, pembelajarannya juga lebih berpusat pada siswa sedangkan guru berperan sebagai pembimbing yang memfasilitasi kegiatan siswa. Pembelajaran konvensional yang digunakan di SD adalah pembelajaran dengan pendekatan saintifik yang menekankan pada aktivitas siswa melalui kegiatan mengamati, menanya, menalar, mengasosiasi dan mengomunikasikan. Pembelajaran konvensional yang diterapkan menggunakan 3 tahap pembelajaran yaitu, pendahuluan, kegiatan inti dan penutup. Aktivitas siswa pada kegiatan inti meliputi lima pengalaman belajar tanpa menggunakan sintaks model pembelajaran tertentu. Meski telah menggunakan kurikulum 2013 dengan pendekatan saintifik, masih banyak siswa yang kurang aktif dan kurang bersemangat mengikuti pembelajaran sehingga materi yang diberikan tidak bisa diterima maksimal oleh siswa.

Pada tanggal 14 - 16 Januari 2019 dilakukan pengumpulan data nilai siswa kelas V. Berdasarkan data yang diperoleh diketahui bahwa 55\% dari populasi atau 298 siswa dari 523 siswa memperoleh nilai kompetensi pengetahuan IPA di bawah KKM yaitu 75. Selain itu, dalam proses pembelajaran siswa cenderung menghafal materi sehingga siswa lebih banyak mengingat informasi tanpa dituntut memahami materi yang diingatnya tersebut. Hal ini bertentangan dengan teori belajar konstruktivisme yang mengatakan bahwa pengetahuan bukan sekedar menghafal, akan tetapi proses memperoleh pengetahuan itu yang penting. Untuk itu peneliti mencoba memberikan inovasi dengan menerapkan model pembelajaran kooperatif tipe Group Investigation dengan harapan bahwa model pembelajaran Group Investigation dapat membantu siswa memahami muatan materi IPA lebih baik. Dari informasi yang diperoleh, SD Negeri Gugus I Kuta Utara belum pernah menerapkan model pembelajaran Group Investigation berbantuan media flash card.

Model Group Investigation dirancang agar siswa bekerja dalam kelompok untuk memecahkan masalah dan mengembangkan keterampilan meneliti. Dengan bekerja secara kelompok anak akan mendapatkan pengalaman untuk mendengar pendapat dan pandangan orang lain, sehingga ia dapat bersikap realitis terhadap pendapatnya sendiri. Seorang anak mungkin dapat lebih mudah menjelaskan konsep yang telah mereka pahami kepada kawannya yang belum mengerti disebabkan anak lebih mudah berkomunikasi dengan sesama anak. Sintaks Group Investigation meliputi pertama identifikasi topik, kedua merencanakan tugas, ketiga melakukan investigasi, keempat membuat laporan akhir, kelima mempresentasikannya dan keenam evaluasi. Model Group Investigation ini membantu siswa memperoleh pengetahuannya dari berbagai sumber mulai dari sumber buku, internet maupun teman belajarnya. Model Group Investigation memberi kebebasan pada siswa untuk memilih sub topiknya sehingga siswa dapat lebih termotivasi dalam menginvestigasi suatu topik. Dalam model ini juga masing-masing siswa akan mendapatkan perannya dalam bekerja sesuai kesepakatan kelompok sehingga siswa akan merasa berharga dan bertanggung jawab dalam menyelesaikan tugas. Dalam belajar bersama, diharapkan siswa dapat melihat teman sejawatnya sebagai model yang disiplin dan giat belajar sehingga mereka akan termotivasi untuk membantu menyelesaikan tugas.

Selain menggunakan model pembelajaran yang tepat, guru juga dapat mempertimbangkan penggunaan media. Munadi (2013:185) mengatakan, "penggunaan media atau alat bantu disadari oleh banyak praktisi pendidikan sangat membantu aktivitas proses pembelajaran baik di dalam maupun di luar kelas, terutama membantu peningkatan prestasi belajar siswa". Media dapat membantu siswa mengkonkretkan pembelajaran yang diterima. Namun pada kenyataannya, penggunaan media dalam proses pembelajaran masih kurang. Hal ini ditemukan saat observasi, dalam mengajar buku teks dan papan tulis masih menjadi andalan, media/alat bantu tambahan jarang digunakan.

Pembelajaran IPA menyangkut tentang hal-hal yang terjadi di alam. Namun tidak semua yang ada di alam dapat dilihat/dirasakan secara langsung oleh manusia. Dalam pembelajaran, media pembelajaran menjadi salah satu perantara pesan untuk menyampaikan hal yang susah untuk dikonkretkan. Media flash card menjadi salah satu media visual yang dapat membantu guru menyampaikan materi untuk mencapai tujuan pembelajaran. Media flash card dirasa cocok untuk membantu siswa dalam mempelajari IPA. Media ini berukuran $25 \times 30 \mathrm{~cm}$, sehingga mudah dilihat oleh seluruh siswa. Media flash card merupakan kartu berisi gambar, teks, atau tanda simbol yang mengingatkan dan menuntun peserta didik kepada sesuatu 
yang berhubungan dengan gambar itu. Media flash card berfungsi sebagai petunjuk-petunjuk kecil yang dapat membantu siswa menemukan jawaban dari permasalahan.

Susilana dan Riyana (2009:95) terbagi menjadi empat yaitu, mudah dibawa, praktis, gampang diingat dan menyenangkan. Selain itu media flash card adalah media yang mudah digunakan dan dibuat oleh siapa saja. Media flash card dibuat dari karton dan dilapisi lakban sehingga dapat digunakan berkalikali. Selain itu, dalam penggunaannya tidak perlu bergantung pada listrik sehingga dapat digunakan kapan saja.

Berdasarkan uraian yang telah dipaparkan, maka dilakukan sebuah penelitian dengan judul "Pengaruh Model Pembelajaran Group Investigation berbantuan Media Flash Card terhadap Kompetensi Pengetahuan IPA Siswa Kelas V SD Negeri Gugus I Kuta Utara Tahun Ajaran 2018/2019. Tujuan dari penelitian ini adalah Untuk mengetahui perbedaan yang signifikan penguasaan kompetensi pengetahuan IPA antara kelompok siswa yang dibelajarkan melalui model pembelajaran Group Investigation berbantuan media flash card dengan kelompok siswa yang dibelajarkan melalui pembelajaran konvensional pada siswa kelas V SD Negeri Gugus I Kuta Utara Tahun Ajaran 2018/2019.

\section{METODE PENELITIAN}

Pelaksanaan penelitian dilakukan di SD Gugus I Kuta Utara. Penelitian ini dilaksanakan pada semester 2 pada bulan Mei 2019. Terdapat 12 kali pertemuan dalam penelitian ini yang terdiri dari 6 kali di kelompok eksperimen dan 6 kali di kelompok kontrol. Jumlah perlakuan yang diberikan telah disesuaikan dengan jam pelajaran terakit materi dalam penelitian ini yang telah diatur dalam kurikulum.

Jenis penelitian yang digunakan adalah eksperimen semu (quasi eksperimental). Penelitian eksperimen semu ini membandingkan dua jenis pembelajaran model Group Investigation berbantuan media flash card dengan pembelajaran konvensional, yang mana kedua pembelajaran tersebut mempunyai pengaruh terhadap satu variabel terikat (kompetensi). Hal ini dikarenakan variabel terikat yang diteliti tidak dapat diawasi dan dikontrol secara ketat. Desain eksperimen yang digunakan adalah "non-equivalent control group design" sebagai berikut.

$$
\mathbf{O}_{1} \mathbf{X} \quad \mathbf{O}_{2}
$$

\section{Gambar 1. Desain Eksperimen Non-equivalent Control Group Design}

Pada desain ini kedua kelompok yang akan diteliti diberikan pre-test dan post-test. Pre-test digunakan untuk penyetaraan kelompok. Teknik yang digunakan dalam penyetaraan kelompok adalah dengan menggunakan uji-t. Setelah itu peneliti memberikan perlakuan, yaitu dengan menerapkan model Group Investigation berbantuan media flash card kepada kelompok eksperimen dan pembelajaran konvensional pada kelas kontrol.

Populasi adalah keseluruhan objek dalam suatu penelitian (Agung, 2014:69). Populasi dalam penelitian ini adalah kelas V SD Negeri Gugus I Kuta Utara yang terdiri dari 14 kelas dengan 523 siswa. Sampel adalah sebagian dari populasi yang diambil, yang dianggap mewakili seluruh populasi dan diambil dengan menggunakan teknik tertentu (Agung, 2012:69). Kegunaan sampel dimaksudkan bila terdapat populasi yang besar dan peneliti tidak mungkin mempelajari semua yang ada pada populasi, maka peneliti dapat menggunakan sampel yang diambil dari populasi. Sampel dalam penelitian ini adalah kelas VB SD No. 4 Dalung dan kelas VA SD No. 5 Dalung. Pemilihan sampel dilakukan melalui teknik random sampling. Setelah mendapatkan dua kelas sampel, kedua kelas tersebut diberikan pre-test untuk diuji kesetaraannya dengan uji-t. Setelah terbukti setara, kedua kelas tersebut diundi kembali untuk mendapatkan kelas eksperimen dan kelas kontrol. Dalam penelitian ini, kelas VB SD No. 4 Dalung sebagai kelas eksperimen terdiri dari 30 siswa dan kelas VA SD No. 5 Dalung sebagai kelas kontrol terdiri dari 33 siswa.

Pengaruh dalam penelitian semata-mata karena perlakuan yang diberikan, hal ini berkaitan dengan validitas penelitian. Validitas penelitian dapat dibedakan menjadi dua, yaitu validitas internal dan eksternal sebagai berikut. Validitas internal menyangkut tingkat kualitas ketepatan pengendalian aspekaspek fisik-psikologis pelaksanaan penelitian dan pemilihan/penggunaan berbagai instrumen dalam pelaksanaan penelitian (Dantes, 2012:88). Cara yang tepat untuk menentukan validitas internal adalah dengan cara mengidentifikasi sebanyak mungkin perlakuan terhadap perlakuan terhadap validitas internal. Faktor-faktor yang memengaruhi validitas internal antara lain adalah sejarah, kematangan, dan seleksi kelompok. Sedangkan validitas eksternal mengacu pada sejauh mana suatu hasil penelitian dapat 
digeneralisasikan (Dantes, 2012:87). Beberapa ancaman yang berkaitan dengan validitas eksternal ini meliputi, interaksi antara perlakuan dan orang, interaksi antara perlakuan dan latar, dan interaksi antara perlakuan dan waktu.

Metode pengumpulan data pada penelitan ini adalah metode tes objektif dalam bentuk pilihan ganda biasa.Tes yang akan digunakan harus diujicobakan terlebih dahulu untuk ketepatan dalam penggunaan instrumen tes tersebut. Instrumen tes terlebih dahulu diuji ahlii oleh para ahli pada bidangnya atau yang berkompeten. Selanjutnya, instrumen penelitian diujicobakan yang terdiri dari uji validitas, uji daya beda, uji tingkat kesukaran dan uji reliabilitas.

Dalam menguji validitas yang digunakan adalah uji validitas isi dan uji validitas butir. Pengaruh dalam penelitian semata-mata karena perlakuan yang diberikan, hal ini berkaitan dengan validitas penelitian. Validitas penelitian dapat dibedakan menjadi dua, yaitu validitas internal dan eksternal sebagai berikut. Validitas isi adalah validitas dari segi isinya atau apabila mengukur tujuan khusus tertentu yang sejajar dengan isi atau materi pelajaran yang diberikan. Uji validitas isi dalam penelitian ini dengan menyusun instrumen berdasarkan kisi-kisi yang merujuk pada kurikulum dan meminta pendapat ahli/pakar. Dalam menguji validitas butir kompetensi pengetahuan IPA dalam bentuk obejktif pilihan ganda biasa digunakan rumus koefesien korelasi point biserial $\left(\mathrm{r}_{\mathrm{pbi}}\right)$. Dari 50 soal yang diujikan diperoleh hasil 30 soal yang valid.

Selanjutnya, dilakukan uji daya beda. Daya beda item menurut Sudijono (2016:385) adalah kemampuan suatu butir item tes hasil belajar untuk dapat membedakan (=mendiskriminasi) antara testee yang berkemampuan tinggi (=pandai), dengan testee yang berkemampuan rendah (=bodoh). Apabila indeks diskriminasi suatu soal mendekati nilai 0,00 maka daya pembeda soal tersebut sangat jelek. Indeks diskriminasi butir soal bernilai negative antara 0,00 sampai -1,00 ini berarti siswa kurang mampu banyak menjawab benar. Sebaliknya, banyak siswa yang pintar menjawab salah. Sedangkan jika suatu butir soal memiliki indeks diskriminasi 0,00 berarti soal tersebut tidak memiliki daya pembeda, artinya baik siswa pandai maupun yang kurang mampu menjawab benar soal tersebut. Angka yang menunjukkan besarnya daya pembeda disebut indeks diskriminatif, disingkat (D).

Untuk menentukan kelompok atas dan kelompok bawah adalah dengan mengambil masingmasing 27\% dari jumlah sampel untuk kelompok atas dan kelompok bawah. Proses penentuan kelompok atas dan kelompok bawah adalah dengan cara mengurutkan skor setiap siswa, dari skor tertinggi sampai skor terendah. Kemudian diambil 27\% kelompok atas dan 27\% kelompok bawah.

Setelah menguji daya beda selanjutnya dalam pengujian instrumen pengumpulan data dilaksanakan menguji tingkat kesukaran. Menguji tingkat kesukaran ada dua yaitu tingkat kesukaran butir tes dan tingkat kesukaran perangkat tes. "Tingkat kesukaran butir tes merupakan bilangan yang menunjukkan proporsi peserta tes yang menjawab betul butir soal yang tersebut" (Agung, 2014).

Tingkat kesukaran dapat dipandang sebagai kesanggupan atau kemampuan siswa menjawab tes yang diberikan. Sedangkan tingkat kesukaran perangkat tes adalah bilangan yang menunjukkan rata-rata proporsi siswa yang dapat menjawab seluruh tes tersebut. Tingkat kesukaran suatu butir soal dinyatakan dengan bilangan yang disebut dengan tingkat kesukaran. Tingkat kesukaran suatu butir soal berkisar antara nilai 0,00 sampai dengan 1,00 .

Selain uji validitas hal kedua yang perlu dalam penyusunan dan pengembangan instrumen adalah uji reliabilitas. Reliabilitas dapat dikatakan sebagai ketelitian dan ketepatan teknik pengukuran. Semakin reliabel suatu instrumen penelitian maka semakin yakin hasil suatu instrumen penelitian tersebut mempunyai hasil yang sama ketika dilakukan tes kembali. Uji reliabilitas dilakukan terhadap butir soal yang valid saja. Uji reliabilitas tes yang bersifat dikotomi ditentukan dengan rumus Kuder Richadson (KR20).

Dalam pemberian interpretasi terhadap koefisien reliabilitas tes $\left(\mathrm{r}_{11}\right)$ pada umumnya digunakan patokan sebagai berikut: (1) Apabila $r_{11} \geq 0,70$ berarti tes kompetensi pengetahuan IPA yang sedang diuji realibilitasnya dinyatakan reliabel, (2) Apabila $r_{11}<0,70$ berarti tes kompetensi pengetahuan IPA yang sedang diuji realibilitasnya dinyatakan unrealiabel. (Sudijono, 2016).

Berdasarkan hasil perhitungan terhadap 30 butir tes yang dinyatakan valid dan memiliki daya beda cukup sampai dengan baik sekali, maka diperoleh $r_{11}=0,956$ Berdasarkan hal tersebut, maka $r_{11}>$ $0,70(0,956>0,70)$ yang berarti tes objektif pilihan ganda biasa pada penelitian ini tergolong reliabel.

Setelah data dikumpulkan, data tersebut dianalisis menggunakan analisis statistik deskriptif dan analisis statistik inferensial. Analisis statistik deskriptif meliput mean, median, modus, standar deviasi dan varians. Sedangkan analisis statistik inferensial yang digunakan untuk menguji hipotesis adalah uji-t. Sebelum dilakukan uji-t, terlebih dahulu dilakukan uji normalitas sebaran data menggunakan chi-kuadrat dan uji homogenitas varians antar kelompok menggunakan rumus uji Fisher. 
Uji normalias sebaran data menggunakan rumus chi-kuadrat. Kriteria dalam pengujian untuk

teknik chi-kuadrat yaitu apabila nilai $\chi 2$ hitung $\leq$ nilai $\chi 2$ tabel, maka Ho diterima, dan Ha ditolak yang artinya data tersebut berdistribusi normal pada taraf signifikansi $5 \%$ dan $\mathrm{dk}=\mathrm{k}-1$. Untuk menguji homogenitas varians atar kelompok menggunakan rumus uji Fisher (F). Kriteria dalam pengujian ini

adalah apabila nilai $\mathrm{F}_{\text {hitung }} \leq$ nilai $\mathrm{F}_{\text {tabel }}$ maka data tersebut homogen pada taraf signifikansi 5\% derajat kebebasan untuk pembilang $\mathrm{n}_{1}-1$ dan derajat kebebasan untuk penyebut $\mathrm{n}_{2}-1$.

Setelah uji prasyarat dipenuhi maka uji hipotesis dengan menggunakan statistik parametrik dapat dilakukan. Pengujian hipotesis penelitian menggunakan uji-t. Karena anggota sampel penelitian ini $\mathrm{n}_{1} \neq \mathrm{n}_{2}$ dan varians homogen, maka digunakan uji-t dengan rumus polled varians. Kriteria pengujian hipotesis yang dipergunakan pada taraf signifikansi $5 \%$ dengan $\mathrm{dk}_{1}+\mathrm{n}_{2}-2$ adalah jika harga $\mathrm{t}_{\text {hitung }} \leq \mathrm{t}_{\text {tabel, }}$, maka Ho diterima dan Ha ditolak.

\section{ANALISIS DAN PEMBAHASAN}

Kelas VB No. 4 Dalung ditetapkan sebagai kelompok eksperimen yang diberi perlakuan berupa pengaruh model Group Investigation berbantuan media flash card sebanyak 6 kali pertemuan, selanjutnya diberikan post-test untuk memperoleh hasil kompetensi pengetahuan IPA.

Nilai mean atau rata-rata kompetensi pengetahuan IPA siswa yang dibelajarkan melalui model

Group Investigation berbantuan media flash card, yaitu $\bar{X}=79,90$ dengan varians 34,852 dan standar deviasi $(s=5,904)$, sedangkan nilai mean atau rata-rata kompetensi pengetahuan IPA siswa yang dibelajarkan melalui pembelajaran konvensional, yaitu $\bar{X}=69,85$ dengan varians 40,195 dan standar deviasi $(s=6,340)$.

Perhitungan analisis data hasil penelitian yang diperoleh menunjukkan bahwa kompetensi pengetahuan IPA kelompok eksperimen yakni siswa yang mengikuti pembelajaran menggunakan model Group Investigation berbantuan media flash card memiliki nilai mean lebih tinggi daripada kelompok

kontrol yaitu $\bar{X}=79,90>\bar{X}=69,85$. Perbandingan data hasil nilai kompetensi IPA antara kelompok eksperimen dan kelompok kontrol disajikan dalam bentuk histogram seperti gambar 2 berikut ini.

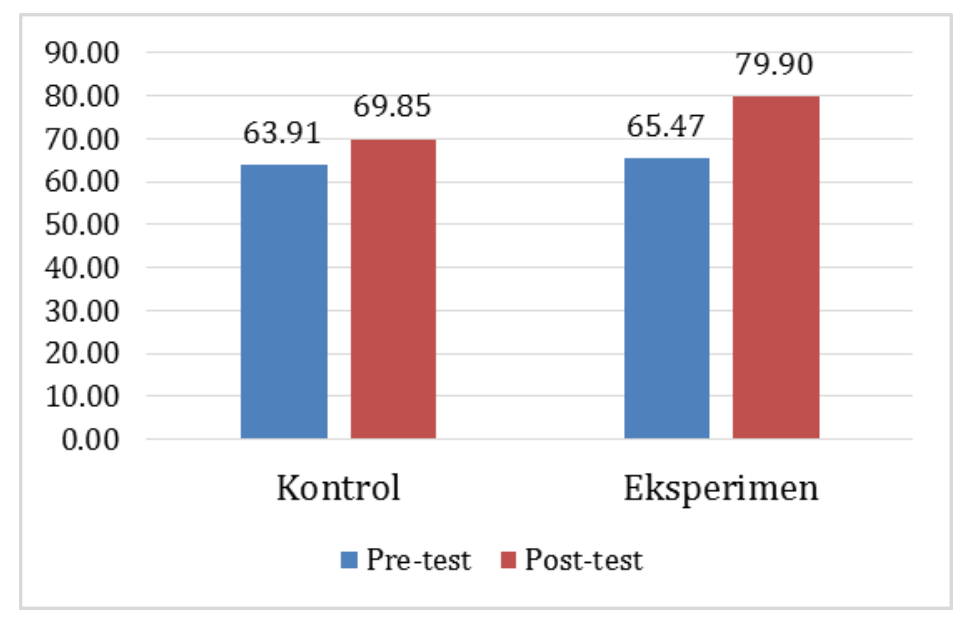

Gambar 2. Grafik Histogram Perbandingan Data Hasil Nilai Kompetensi IPA

Selanjutnya, data berupa nilai pre-test dan post-test yang telah diperoleh selanjutnya dilakukan uji prasyarat yaitu dengan melakukan uji normalitas sebaran data menggunakan rumus chi-kuadrat dan uji homogenitas varians dengan rumus Fisher. Ringkasan perhitungan uji normalitas disajikan pada tabel 1 berikut. 
Tabel 1. Ringkasan Perhitungan Uji Normalitas

\begin{tabular}{clccc}
\hline No. & \multicolumn{1}{c}{ Kelompok Data } & $\chi^{2}$ hitung & $\chi^{2}$ tabel & Keterangan \\
\hline 1 & Pre-Test kelompok eksperimen & 4,199 & 7,815 & Normal \\
2 & Post-Test kelompok eksperimen & 5,274 & 7,815 & Normal \\
3 & Pre-Test kelompok kontrol & 2,902 & 7,815 & Normal \\
4 & Post-Test kelompok kontrol & 4,205 & 7,815 & Normal \\
\hline
\end{tabular}

Setelah data berdistribusi normal, selanjutnya dilakukan uji homogenitas. Ringkasan perhitungan uji homogenitas disajikan pada tabel 2 berikut.

Tabel.2. Rekapitulasi Hasil Uji Homogenitas Varians dengan Uji-F

\begin{tabular}{clcccc}
\hline $\begin{array}{c}\text { No } \\
\text {. }\end{array}$ & \multicolumn{1}{c}{ Kelompok Data } & $\begin{array}{c}\text { Varians } \\
\left(\mathbf{S}^{\mathbf{2}} \mathbf{s}\right.\end{array}$ & $\mathbf{F}_{\text {hitung }}$ & $\mathbf{F}_{\text {Tabel }}$ & Keterangan \\
\hline \multirow{2}{*}{1} & Pre-Test kelompok eksperimen & 44,95 & \multirow{2}{*}{1,20} & \multirow{2}{*}{4,00} & Homogen \\
& Pre-Test kelompok kontrol & 37,59 & & & \\
\multirow{2}{*}{2} & Post-Test kelompok eksperimen & 34,85 & \multirow{2}{*}{1,15} & 4,00 & Homogen \\
\hline
\end{tabular}

Setelah data berdistribusi normal dan homogen selanjutnya dilakukan uji-t. Sebelum melakukan uji-t data dianalisis menggunakan gain score yaitu post-test - pre-test. Setelah menghitung gain score pretest dan post-test kelompok eksperimen dan kelompok kontrol selanjutnya dilakukan perhitungan uji-t dengan kriteria penilaian pada taraf signifikansi $5 \%$ dengan $d k n_{1}+n_{2}-2$ adalah jika harga $t_{\text {hitung }} \leq t_{\text {tabel, }}$, maka $\mathrm{H}_{\mathrm{o}}$ diterima dan $\mathrm{H}_{\mathrm{a}}$ ditolak.

Melalui analisis data Gain kompetensi pengetahuan IPA siswa kelompok eksperimen dan kelompok kontrol yang berdasarkan pada nilai pre-test dan nilai post-test, maka diperoleh $t_{\text {hitung }}=5,003$ dan $t_{\text {tabel }}=2,000$, yaitu pada taraf signifikan dan $5 \%$ dengan $\mathrm{dk}=30+33-2=61$. berikut

Perhitungan rekapitulasi hasil analisis uji-t kelompok sampel penelitian ini disajikan dalam tabel

Tabel 3. Rekapitulasi Hasil Analis Data Kompetensi Pengetahuan IPA menggunakan Uji-t

\begin{tabular}{clcccccc}
\hline No & \multicolumn{1}{c}{ Sampel } & $\begin{array}{c}\text { Rata- } \\
\text { rata }\end{array}$ & Varians & $\mathbf{N}$ & $\mathbf{t}_{\text {hitung }}$ & $\mathbf{t}_{\text {tabel }}$ & Kesimpulan \\
\hline 1 & Kelas Eksperimen & 0,402 & 0,038 & 30 & 5,003 & 2,000 & $\mathrm{H}_{\mathrm{o}}$ ditolak \\
2 & Kelas Kontrol & 0,160 & 0,014 & 33 & & \\
\hline
\end{tabular}

Sehingga dapat diketahui bahwa $t_{\text {hitung }}=5,003>t_{\text {tabel }}=2,000$. Dengan demikian, maka $H_{0}$ ditolak dan $\mathrm{H}_{\mathrm{a}}$ diterima. Hal ini menunjukkan bahwa terdapat perbedaan yang signifikan kompetensi pengetahuan IPA antara kelompok siswa yang dibelajarkan menggunakan model Group Investigation berbantuan media flash card dengan kelompok yang dibelajarkan menggunakan pembelajaran konvensional pada siswa kelas V di SD Negeri Gugus I Kuta Utara tahun ajaran 2018/2019.

Pada kelompok eksperimen, kegiatan pembelajaran dalam muatan materi IPA menggunakan model pembelajaran Group Investigation berbantuan media flash card berjalan dengan baik. Siswa terlihat antusias dalam belajar, lebih aktif dalam berpendapat, kebebasan serta penghargaan diri siswa juga berkembang dengan menggunakan model Group Investigation.

Penggunaan flash card membantu siswa untuk mengkonkretkan benda-benda yang tidak bisa ditemukan secara langsung di lingkungan siswa. Dalam melaksanakan model Group Investigation berbantuan flash card siswa mengikuti pembelajaran mulai dari tahap seleksi topik, merencanakan penelitian, melakukan investigasi, merencanakan presentasi, melakukan presentasi dan evaluasi. Berdasarkan 6 tahapan tersebut, media flash card digunakan pada tahap pemilihan topik, tahap siswa melakukan investigasi serta pada tahap evaluasi. Pada tahap pemilihan topik, guru menunjukkan flash card di depan kelas. Para siswa menebak gambar yang tertera. Ketika melakukan investigasi, para siswa mencari jawaban dari lembar kerja dibantu dengan flash card yang telah dibagikan guru. Sedangkan pada tahap evaluasi, guru melakukan permainan menggunakan kartu flash card. Dalam permainan ini 
perwakilan dari tiap kelompok menjawab pertanyaan guru dengan menunjukkan flash card yang berkaitan.

Kegiatan kelompok yang terjadi menyebabkan guru dan murid memiliki status yang sama di hadapan masalah yang dipecahkan dengan peranan yang berbeda. Dengan demikian, siswa lebih memahami materi serta siswa dapat menemukan pengetahuannya sendiri. Pembelajaran menjadi berpusat pada siswa dan guru berperan sebagai fasilitator.

Berbeda pada kelompok kegiatan pembelajaran konvensional yang mengutamakan metode ceramah. Dalam proses belajar mengajar, pembelajaran masih terpusat pada guru. Guru menjelaskan materi dan siswa mencatatnya, guru memberikan tugas dan siswa mengerjakannya. Siswa lebih sering mendengarkan penjelasan guru untuk memahami materi dan mengerjakan soal-soal di buku paket atau LKS untuk mendalami materi. Proses belajar megajar dalam pembelajaran konvensional lebih berpusat pada guru sebagai pemberi materi, siswa hanya menerima dan mengerjakan tugas sesuai dengan arahan guru.

Berbeda dengan model pembelajaran Group Investigation yang memberikan kebebasan pada murid untuk memilih topik, membagi tugas pengerjaan kelompoknya, dan menyiapakan presentasi mereka sendiri. Dengan demikian, perbedaan hasil kompetensi pengetahuan IPA dapat terlihat dari langkah pembelajaran yang dilakukan pada kedua kelompok tersebut, hasil analisis uji hipotesis, dan nilai rerata siswa yang dibelajarkan melalui model pembelajaran Group Investigation berbantuan media flash card dengan siswa yang dibelajarkan melalui pembelajaran konvensional.

Pada perolehan hasil perhitungan analisis data menunjukkan bahwa rata-rata Gain Score kompetensi pengetahuan IPA siswa pada kelompok eksperimen yaitu $\bar{X}=14,433$ lebih dari rata-rata pada kelompok kontrol yaitu $\bar{X}=5,939$. Hal ini menunjukkan bahwa kompetensi pengetahuan IPA pada kelompok siswa yang dibelajarkan menggunakan model Group Investigation berbantuan media flash card lebih baik daripada kelompok siswa yang dibelajarkan menggunakan pembelajaran konvensional. Dengan demikian dapat dikatakan bahwa terdapat pengaruh model Group Investigation berbantuan media flash card terhadap kompetensi pengetahuan IPA pada siswa kelas V SD Gugus I Kuta Utara tahun ajaran $2018 / 2019$.

Hasil temuan pada penelitian ini memiliki persamaan dengan penelitian sebelumnya yang relevan dan memperkuat hasil penelitian yang diperoleh. Hal tersebut di dukung oleh Hayatun, Abdi dan Harun (2017) dan Intarini, Ni Made Wila (2018) yang membuktikan bahwa hasil belajar siswa pada kelompok eksperimen yang dibelajarkan menggunakan model Group Investigation lebih baik daripada hasil belajar siswa pada kelompok kontrol yang dibelajarkan menggunakan pembelajaran konvensional. Adapun persamaan dengan penelitian ini adalah sama-sama menggunakan model pembelajaran Group Investigation. Perbedaan penelitian ini dengan penelitian yang dilakukan oleh Hayatun, Abdi dan Harun (2017) adalah variabel terikatnya. Variabel yang diteliti adalah hasil belajar IPS. Sedangkan perbedaan penelitian ini dengan penelitian yang dilakukan oleh Ni Made Wila (2018) adalah pada media yang digunakan. Media yang digunakan adalah multimedia.

Berdasarkan pemaparan tersebut, dapat disimpulkan bahwa terdapat perbedaan yang signifikan antara penguasaan kompetensi pengetahuan IPA antara kelompok siswa yang dibelajarkan melalui model pembelajaran Group Investigation berbantuan media flash card pada siswa kelas V SD Negeri Gugus I Kuta Utara Tahun Ajaran 2018/2019.

\section{KESIMPULAN}

Berdasarkan hasil analisis data kompetensi pengetahuan IPA siswa yang dibelajarkan melalui model pembelajaran Group Investigation berbantuan media flash card kelas V SD Negeri Gugus I Kuta Utara Tahun Ajaran 2018/2019 diperoleh rata-rata (mean) 79,90, varian 34,852 dan standar deviasi 5,904. Rata-rata (mean) 79,90 dikonversikan ke dalam kriteria PAN berada pada kriteria sangat tinggi.

Kompetensi pengetahuan IPA kelompok siswa yang dibelajarkan melalui model pembelajaran konvensional pada siswa kelas V SD Negeri Gugus I Kuta Utara 2018/2019 memperoleh rata-rata (mean) 69,85, varian 40,195, dan standar deviasi 6,340. Rata-rata (mean) 69,85 dikonversikan ke dalam kriteria PAN berada pada kriteria tinggi.

Hasil perhitungan uji-t diperoleh $t_{\text {hitung }}=5,003$. Kemudian pada tara signifikansi $5 \%$ dan dk $=\mathrm{n} 1+$ $n 2-2(30+33-2=61)$ diperoleh $t_{\text {tabel }}=2,000$. Maka $t_{\text {hitung }}>t_{\text {tabel }}$ yaitu $5,003>2,000$. Jadi, $H_{0}$ ditolak ini berarti terdapat perbedaan yang signifikan penguasaan kompetensi pengetahuan IPA antara kelompok siswa yang dibelajarkan melalui model pembelajaran Group Investigation berbantuan media flash card dengan kelompok siswa yang dibelajarkan melalui pembelajaran konvensional pada siswa kelas V SD Negeri Gugus I Kuta Utara Tahun Ajaran 2018/2019. Dapat dikatakan bahwa model Group Investigation 
berbantuan flash card berpengaruh terhadap kompetensi pengetahuan IPA siswa kelas V SD Negeri Gugus I Kuta Utara Tahun Ajaran 2018/2019.

Ada beberapa saran yang dapat diajukan berdasarkan temuan dan kajian penelitian ini kepada guru, kepala sekolah dan peneliti lain. Bagi guru disarankan agar menggunakan model pembelajaran Group Investigation sebagai model pembelajaran alternatif pada pembelajaran IPA. Bagi kepala sekolah, disarankan agar menggunakan hasil penelitian ini sebagai alternatif dalam mengelola pembelajaran agar sesuai dengan karakteristik pembelajaran IPA. Bagi peneliti lain, disarankan agar dapat melaksanakan penelitian serupa di SD yang lain dengan menjadikan penelitian ini sebagai referensi.

\section{DAFTAR PUSTAKA}

Agung, A.A Gede. 2014. Metodologi Penelitian Pendidikan. Yogyakarta: Aditya Media Publishing.

Agung, A.A Gede. 2016. Statistika Dasar untuk Pendidikan. Yogyakarta: Deepublish.

Agung, A.A Gede. 2015. Buku Ajar Evaluasi Pendidikan. Singaraja: Jurusan Teknologi Pendidikan, Fakultas Ilmu Pendidikan Universitas Pendidikan Ganesha

Arsyad, Azhar. 2016. Media Pembelajaran. Jakarta: Rajawali Pers.

Aqib, Zainal dan Ali Murtadio. 2016. Kumpulan Metode Pembelajaran Kreatif dan Inovatif. Bandung: Sarana Tutorial Nurani Sejahtera.

Dantes. 2012. Metode Penelitian.Yogyakarta: Penerbit Andi.

Dantes. 2017. Desain Eksperimen dan Analisis Data. Depok: Rajawali Pers.

Darmadi, Hamid. 2014. Metode Penelitian Pendidikan dan Sosial. Bandung: Alfabeta.

Candiasa, I Made. 2011. Pengujian Instrumen Penelitian Disertai Aplikasi ITEMAN dan BIGSTEPS. Singaraja: Undiksha Press.

Hamzah B. Uno dan Nurdin Mohamad. 2012. BELAJAR DENGAN PENDEKATAN PAIKEM: Pembelajaran Aktif, Inovatif, Lingkungan, Kreatif, Eektif, Menarik. Jakarta: Bumi Aksara

Hayatun, Abdi dan Harun. (2017). Penerapan Model Pembelajaran Kooperatif Tipe Group Investigation dengan menggunakan Media Pembelajaran Flash Card dan Flipchart untuk meningkatkan hasil belajar IPS terpadu siswa kelas VII SMP Inshafuddin Banda Aceh. Aceh: Unsyiah. Tersedia pada http://www.jim.unsyiah.ac.id/geografi/article/view/5188 (diakses tanggal 28 November 2018)

Intarini, Ni Made Wila. (2018). Pengaruh Model Pembelajaran Group Investigation berbantuan Multimedia terhadap Kompetensi Pengetahuan IPA Siswa Kelas IV SD Gugus I Gianyar Tahun Pelajaran 2017/2018. Bali: Undiksha.

Khodijah, Nyayu. 2014. Psikologi Pendidikan. Jakarta: Rajagrafindo Persada.

Kosasih. 2014. Strategi Belajar dan Pembelajaran. Bandung: Yrma Widya

Koyan. I Wayan. 2012. Statistik Pendidikan Teknik Analisis Data Kuantitatif. Singaraja: Universitas Pendidikan Ganesha

Kurniasih, Imas dan Berlin Sani. 2015. Ragam Pengembangan Model Pembelajaran. Jakarta: Katapena.

Mudadi,Yudhi. 2013. Media Pembelajaran; Sebuah Pendekatan Baru. Jakarta: GP Press Group. 
Ngalimun. 2012. Strategi dan Model Pembelajaran. Banjarmasin: Aswaja Pressindo.

Omeri, Nopan. 2015. Pentingnya Pendidikan Karakter Dalam Dunia Pendidikan. Manajer Pendidikan, Volume 9, Nomor 3, Hal. 464-468. Tersedia Pada: https://ejournal.unib.ac.id/index.php/manajerpendidikan/article/view/1145/0.

Parwati, Nyoman, dkk. 2018. Belajar dan Pembelajaran. Depok: Rajagrafindo Persada.

Rusman. 2014. Model-Model Pembelajaran: Mengembangkan Profesionalisme Guru. Jakarta: PT. Raja Grafindo Persada.

Sahroni, Dapip. 2017. Pentingnya Pendidikan Karakter dalam Pembelajaran. Prosiding Seminar Bimbingan dan Konseling Vol. 1, No. 1, 2017, hlm. 115-124. Tersedia Pada: http://pasca.um.ac.id/conferences/index.php/snbk.

Said, Alamsyah dan Andi Budimanjaya. 2015. 95 Strategi Mengajar Multiple Intelligences. Jakarta: PRENADAMEDIA GROUP.

Samatowa, Usman. 2010. Pembelajaran IPA di Sekolah Dasar. Jakarta:Indeks.

Setyosari, Punaji. 2015. Metode Penelitian Pendidikan \& Pengembangan. Jakarta:Kencana Prenada Group

Shoimin, Aris. 2014. 68 Model Pembelajaran Inovatif dalam Kurikulum 2013. Yogyakarta: AR-RUZZ Media.

Suandi, Nengah, dkk. 2016. Buku Pedoman Penulisan Karya Ilmiah. Singaraja: Universitas Pendidikan Ganesha.

Suardi dan Syofrianisda. 2018. Belajar dan Pembelajaran. Yogyakarta: Parama Ilmu.

Sudijono, Anas. 2016. Pengantar Evaluasi Pendidikan. Jakarta: Rajawali Pers.

Sugiyono.2012. Metode Penelitian Pendidikan. Bandung: Alfabeta.

Sugiyono.2017. Metode Penelitian. Bandung: Alfabeta.

Suryanto, Adi. 2014. Materi Pokok Evaluasi Pembelajaran di SD. Tanggerang: Universitas Terbuka.

Susanto, Pudyo. 2018. Belajar Tuntas. Jakarta: Bumi Aksara.

Susilana, Rudi dan Riyana Cepi. 2009. Media Pembelajaran: Hakikat Pengembangan, Pemanfaatan dan Penilaian. Bandung: Alfabeta.

Suyanto dan Asep Jihad. 2013. Bagaimana menjadi Calon Guru dan Guru Profesional. Yogyakarta: Multi Pressindo.

Taniredja, Tukiran dkk. 2015. Model-model pembelajaran Inovatif dan Efektif. Bandung: Alabeta. 